\title{
15. 卵巣出血に対する腹腔鏡下処置の適応と限界
}

\author{
（東海大学医学部産婦人科学教室）
}

\author{
林田研一・小林善宗・井上正人 \\ 本田育子・淡路 英 雄 - 藤井明和
}

急性腹症のなかでも, 卵巣出血は直沴断処置 を要するもので，速やかな腹腔鏡診断が有効であ る疾患ともい党る. 過去 6 年間化当科で経験した 卵巣出血 22 症例飞対する腹腔鏡下処置を分析し た.

\section{対}

対象 22 名はすべて下腹痛を主訴とし，らち 2 名は尿妊娠反応陽性であった。 対象の平均年齢は 21.7 歳 (19 44 歳), 未婚 12 名, 既婚 10 名でう ち末経産 5 名, 経産 5 名 (1 名は産裤期) であっ た。卵巣への手術既往例は 1 名であった。腹腔鏡 下誩断時又は開腹時の所見, 手術時間, 出血量の 検討を加光るとともに，対象の年齢などの検討に より腹腔鏡処置のみで治療を完了できうる適応と 限界について検討した。

\section{結 果}

対象 22 名のらち, 腹腔鏡下処置の 及で治療を 完了できたのは 11 名(50\%)で，7名 (31.8\%)は 腹腔鏡下診断にひきつら゙き直に開腹処置を行っ た. 4 名 $(18.2 \%)$ は直開腹処置となった。

対象の術前誩断と処置法との関倸は，全体では 術前卵巣出血疑いは 17 例 (77.3\%) で，2 名は子 宮外妊娠を疑い(尿妊娠反応陽性), 3 名は卵巣茥 捻転を疑った，処置法別飞久ると，腹腔鏡処置の 久 11 名での術前診断は卵巣出血疑い 7 名, 外妊 疑い 1 名, 茎揄転疑い 3 名であった. 結局開腹処 置となった計 10 名では 1 名の外妊疑い以外すべ て術前测巣出血を疑っていた。

腹膑内所見より，すでに止血していた症例は 11
名 $(50 \%)$ で，5ち 10 名は腹腔鏡処置のみであっ た. 卵栄出血部位の止血処置 (圧迫, 電気燒灼, 部分綘合）のみで治㙩完了したのは腹腔鏡下処置 の及が 1 名，開腹処置で 4 名であった。他は卵巣 部分切除 ( 2 名)か卵巣摘出 ( 4 名)を行った.

平均出血量は，腹腔鏡下処置のみが $194 \mathrm{ml}(20$ $700 \mathrm{ml})$, 腹腔鏡診断後開腹処置で $866 \mathrm{ml}(70 \sim 1489$ $\mathrm{ml})$, 開腹処置で $743 \mathrm{ml}(323 \sim 1487 \mathrm{ml})$ であり, 当 然出血量の少い症例が腹腔鏡下処置の々で治療完 了する頻度が高いと考兄られた。平均手術時間で みると, 腹腔鏡処置のみで 96 分 (36 185 分), 腹 腔鏡診断後開腹処置で 110 分 (93 155 分), 開腹 処置で 88 分 (45 109 分)であり, 腹腔鏡処置のみ では腹腔内出血の吸引・洗浄に時間がかかったも のと思われた。

対象の平均年龄は, 腹腔鏡下処置のみで 24.2 歳 (19 29 歳)腹腔鏡診断後開腹処置で 27.6 歳 $(20$ 34 歳), 開腹処置で 34.4 歳 (24 44 歳) であり, 腹腔鏡下処置のみでは若年龄が多いことが特徴で あった。

術後平均入院期間は, 腹腔鏡処置のみで 3.9 日 (2〜11日)と短いものですんだ.

\section{結 論}

卵巣出血症例の半数は腹腔鏡処置の久で治療を 完了できたが，その適応は，すでに卵巣出血部位 が止血されており，腹空内出血量が比較的少い若 年齢者の傾向であった。 しかし開腹処置症例の中 飞, 止血例や止血処置の久の症例があり, 腹腔鏡 下処置の々で治療を完了できた可能性が指摘され た。 